\title{
Morphology of the megalopa of the mud crab, Rhithropanopeus harrisii (Gould, 1841) (Decapoda, Brachyura, Panopeidae), identified by DNA barcode
}

\author{
Elena Marco-Herrero • J. Ignacio González-Gordillo • \\ José A. Cuesta
}

Received: 13 June 2013/Revised: 10 January 2014 / Accepted: 16 January 2014/Published online: 28 January 2014

(C) Springer-Verlag Berlin Heidelberg and AWI 2014

\begin{abstract}
The morphology of the megalopa stage of the panopeid Rhithropanopeus harrisii is redescribed and illustrated in detail from plankton specimens identified by DNA barcode (16S mtDNA) as previous descriptions do not meet the current standard of brachyuran larval description. Several morphological characters vary widely from those of other panopeid species which could cast some doubt on the species' placement in the same family. Besides, some anomalous megalopae of $R$. harrisii were found among specimens reared at the laboratory from zoeae collected in the plankton. These anomalous morphological features are discussed in terms of problems associated with laboratory rearing conditions.
\end{abstract}

Keywords Rhithropanopeus harrisii · Panopeidae · Megalopa $\cdot$ Barcode $\cdot$ 16S · Morphology · Anomalies

\section{Introduction}

Currently, three species of Panopeidae are known for the Iberian Peninsula, Panopeus africanus (A. Milne

Communicated by H.-D. Franke.

E. Marco-Herrero $(\square)$ J J. A. Cuesta

Instituto de Ciencias Marinas de Andalucía, CSIC, Avda.

República Saharaui, 2, 11519 Puerto Real, Cádiz, Spain

e-mail: elena.marco@csic.es

J. A. Cuesta

e-mail: jose.cuesta@icman.csic.es

\section{J. I. González-Gordillo}

Departamento de Biología, Universidad de Cádiz, Campus de

Excelencia Internacional del Mar (Ceimar),

11510 Puerto Real, Cádiz, Spain

e-mail: nacho.gonzalez@uca.es
Edwards, 1867), Dyspanopeus sayi (Smith, 1869) and Rhithropanopeus harrisii (Gould, 1841). While P. africanus is an Iberian native species distributed from the Gulf of Cadiz (SW Spain) to the Mondego estuary (NW Portugal), the other two panopeids are introduced species. These are among the most widespread introduced brachyuran species in the world. D. sayi is native to the Atlantic coast of North America from Florida to Canada (Nizinski 2003) and has been introduced to coastal areas of southwest England, Queens Dock, Swansea (Wales) (Ingle 1980; Clark 1986), to the French and Dutch coasts of the North Sea (Vaz et al. 2007), the Black Sea (Micu et al. 2010), and more recently to the Mediterranean Sea, Venice, the Marano and Varano lagoons, the Po River Delta (western Adriatic Sea) (Froglia and Speranza 1993; Mizzan 1995; Florio et al. 2008) and to the east coast of the Iberian Peninsula (Schubart et al. 2012).The first report of a population of $R$. harrisii for the Iberian Peninsula was made by Cuesta et al. (1991) for the Guadalquivir estuary, but populations are present in many European Atlantic estuaries, as well as in some Mediterranean locations. The species has been extensively studied from several perspectives such as ecology, phylogeography and larval biology (Gonçalves et al. 1995; Forward 2009; Projecto-Garcia et al. 2010).

Rhithropanopeus harrisii is a euryhaline crab typically associated with sheltered estuarine habitats. Connolly (1925) described its four zoeal stages and the megalopa, based on larvae reared from eggs in the laboratory. Further descriptions were provided by Hood (1962) and Chamberlain (1962), but the best illustrations of the larval stages are shown in Costlow and Bookhout (1971) (as underlined by Forward 2009). Nevertheless, all descriptions are incomplete compared to the current standard of brachyuran larval descriptions proposed by Clark et al. (1998). 
Traditionally, descriptions of larvae have been accomplished from specimens cultivated in the laboratory under controlled conditions (temperature, salinity, density and absence of predators), and the specimens commonly originated from a single or sometimes from two ovigerous females. These circumstances may contribute to conceal the morphological variability of larvae that can be found in the field, a phenomenon already discussed in the literature for brachyuran larvae (Cuesta et al. 2002).

The use of molecular markers has demonstrated to be a powerful tool in providing accurate identifications for plankton specimens (Pan et al. 2008; Pardo et al. 2009; Ampuero et al. 2010; Marco-Herrero et al. 2013a). The identification of megalopae has traditionally been based on morphological characteristics, but sometimes, it is impossible to get an accurate identification with this approach. In the present study, we used partial sequences of the mitochondrial gene $16 \mathrm{~S}$ as DNA barcode to identify the megalopae collected in the plankton. The $16 \mathrm{~S}$ marker has proven to be an effective tool in studies of decapod crustaceans (Schubart et al. 2000; Porter et al. 2005; Ahyong et al. 2007), not only for the establishment of new species, but also to elucidate the taxonomic validity of closely related species (Schubart et al. 1998, 2001; Spivak and Schubart 2003).

In contrast to traditional descriptions, the megalopae of the present study were obtained from the plankton and identified by DNA barcode. Furthermore, in order to provide a definite morphological description of the megalopa stage of $R$. harrisii, comparisons were made not only with previous descriptions, but also with another set of megalopae which were reared in the laboratory from four zoeae I collected in the plankton.

\section{Materials and methods}

\section{Collection of the megalopae}

Twenty-eight megalopae of $R$. harrisii were collected in July 2007 and four zoeae I in April 2011, all from the plankton of the Guadalete estuary (Cádiz-SW Spain) $\left(36^{\circ} 35^{\prime} 24.09^{\prime \prime} \mathrm{N} 6^{\circ} 13^{\prime} 46.19^{\prime \prime} \mathrm{W}\right)$.

Rearing and description of the megalopae

All megalopae collected were preserved directly in $80 \%$ ethanol. The four zoeae I were placed in beakers containing filtered and well-aerated sea water at a salinity of $32 \pm 1 \%$ and a temperature of $26 \pm 1{ }^{\circ} \mathrm{C}$. The larvae were fed with the rotifer Brachionus plicatilis (fed with Nannochloropsis gaditana). Rearing was finished when all zoeae had molted to the megalopa instar. Megalopa descriptions were based on 10 specimens identified by DNA barcode.

To facilitate the microscopical observation of larvae structures, a digestion-stain procedure was carried out. Firstly, entire specimens were placed for about $10 \mathrm{~min}$ in a watch glass with $2 \mathrm{ml}$ of heated lactic acid. Immediately afterward, three drops of Clorazol Black stain (0.4 g Clorazol Black powder dissolved in $75 \mathrm{ml} 70 \% \mathrm{EtOH}$ ) were added to the heated solution. After 5-10 min, the specimen was removed from the solution and placed on a slide with lactic acid in order to proceed with the dissection of the appendages (Landeira et al. 2009).

Drawings and measurements were made using a Leica MZ6 and Zeiss Axioskop compound microscope with Nomarski interference, both equipped with a camera lucida. All measurements were made by an ocular micrometer. The measurements taken were cephalothorax length (CL) as the distance from the tip of the rostrum to the posterior margin of the cephalothorax and cephalothorax width $(\mathrm{CW})$ as the maximum width of the cephalothorax. Two megalopae identified by DNA barcode were deposited at the Biological Collections of Reference of the Institut de Ciències del Mar (ICM-CSIC) in Barcelona, under accession numbers ICMD13121701 and ICMD13121702.

DNA extraction, amplification and sequencing

The identification of the megalopae was based on partial sequences of the $16 \mathrm{~S}$ rDNA gene. Total genomic DNA was extracted from muscle tissue from 1 to 2 pereiopods of each megalopa and incubated for $1-24 \mathrm{~h}$ in $300 \mu \mathrm{l}$ lysis buffer at $65^{\circ} \mathrm{C}$. Protein was precipitated by addition of $100 \mu \mathrm{l}$ of $7.5 \mathrm{M}$ ammonium acetate and subsequent centrifugation, and DNA precipitation was obtained by addition of $300 \mu \mathrm{l}$ isopropanol and posterior centrifugation. The resulting pellet was washed with ethanol (70\%), dried, and finally resuspended in Milli-Q distilled water.

Target mitochondrial DNA from the large subunit rRNA (16S) gene was amplified with polymerase chain reaction (PCR) and the following cycling conditions for reactions: $2 \mathrm{~min}$ at $95^{\circ} \mathrm{C}, 40$ cycles of $20 \mathrm{~s}$ at $95^{\circ} \mathrm{C}, 20 \mathrm{~s}$ at $45-48{ }^{\circ} \mathrm{C}, 45 \mathrm{~s}$ at $72{ }^{\circ} \mathrm{C}$, and $5 \mathrm{~min}$ at $72{ }^{\circ} \mathrm{C}$. Primers 1472 (5'-AGA TAG AAA CCA ACC TGG-3') (Crandall and Fitzpatrick 1996) and 16L2 (5'-TGC CTG TTT ATC AAA AAC AT-3') (Schubart et al. 2002) were used to amplify $540 \mathrm{bp}$ of $16 \mathrm{~S}$. PCR products were sent to NewBiotechnic and Biomedal companies to be purified and then twodirectional sequencing.

Sequences were edited using the software Chromas version 2.0. The final sequences were blasted on GenBank database to get the best BLAST matches for an accurate identification. Sequences are accessible in GenBank under the accession numbers KJ125076-KJ125077. 


\section{Results}

\section{Barcode identification}

Using the BLAST utility (http://blast.ncbi.nlm.nih.gov/ Blast.cgi), the sequences obtained from the megalopae were compared with those deposited in GenBank. The sequences perfectly fit those of $R$. harrisii, more specifically, no difference (100\% match) was found between the $16 \mathrm{~S}$ sequence for $546 \mathrm{bp}$ and sequences of $R$. harrisii from Woodland Beach, Delaware, USA (ULLZ 3836), GenBank accession number AJ274697.

Nevertheless, three out of four megalopae reared in the laboratory from specimens collected as zoeae $\mathrm{I}$ in the plankton did not show the general morphology and all setation patterns of those megalopal stage of $R$. harrisii which had been directly collected in the plankton. According to the DNA barcode, however, these specimens clearly belong to the same species. We have considered these specimens as "anomalous megalopa" and have provided an additional description of this type of larva.

Description of the megalopa

(Figs. 1a-e; 2a, b, d, e, g; 3a, c, d; 4a-e; 5a, d, e) Size: $\mathrm{CL}=1.18 \pm 0.05 \mathrm{~mm} ; \mathrm{CW}=1.02 \pm 0.05 \mathrm{~mm}$; $N=5$

Cephalothorax (Fig. 1a, b) Rostrum is short and obliquely downward with 2 lateral simple setae at base, anterior end with a median triangular notch; the pedunculated eyes with 8 small simple setae each; hepatic region swollen; one pair each of protogastric, mesobranchial and cardiac protuberances present; and broader posterior part, margins setose.
A
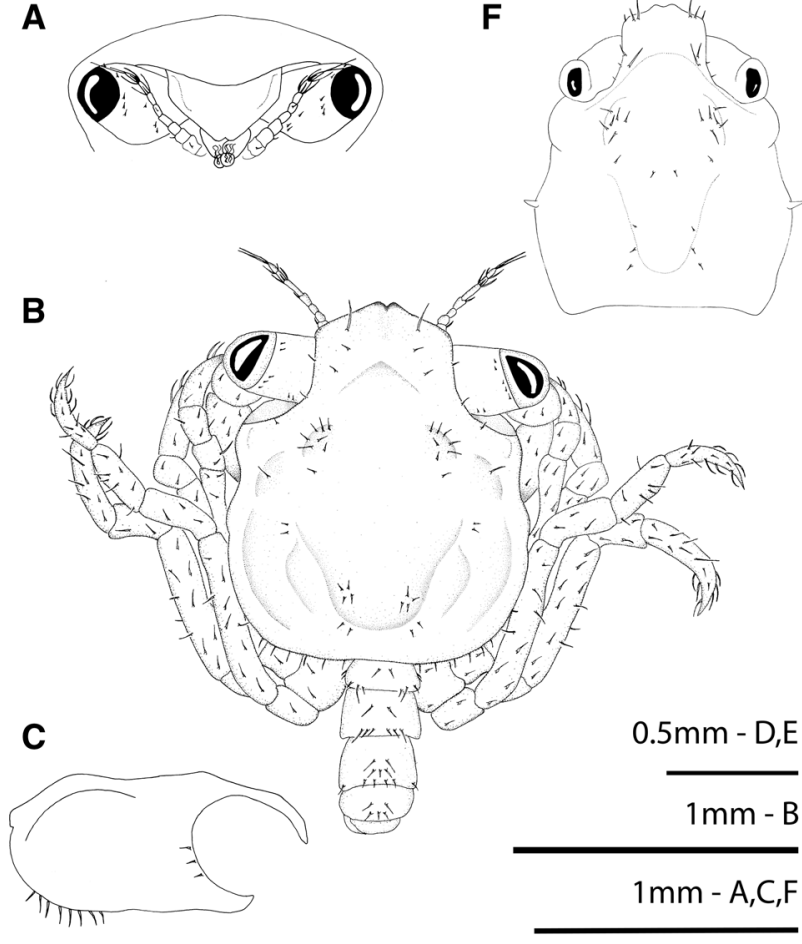

D

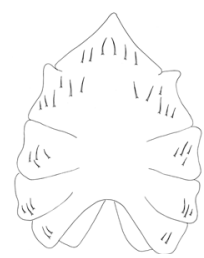

Fig. 1 Rhithropanopeus harrisii (Gould, 1841). Megalopa, a frontal view; b dorsal view; c lateral view of the cephalothorax; d, e sternum; f anomalous megalopa, dorsal view

E

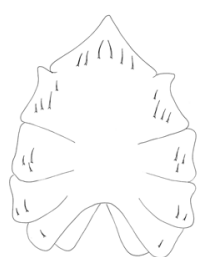

A

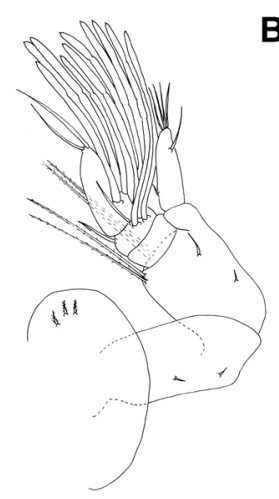

B

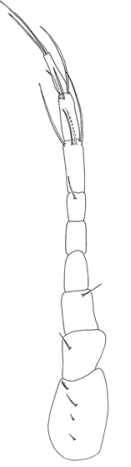

C
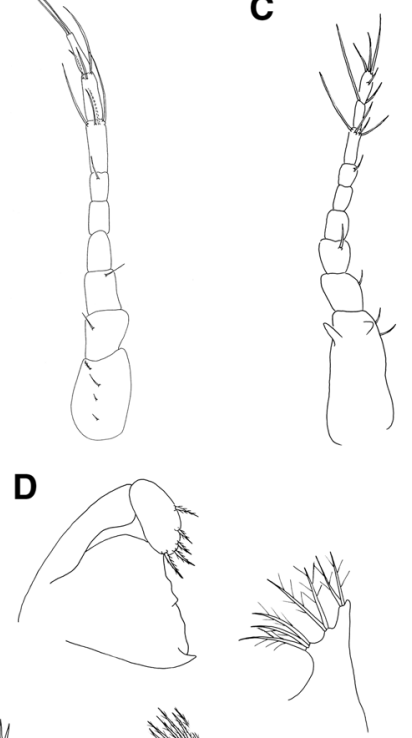

H

$0.2 \mathrm{~mm}-\mathrm{A}, \mathrm{B}, \mathrm{D}-\mathrm{H}$

$0.5 \mathrm{~mm}-\mathrm{C}$
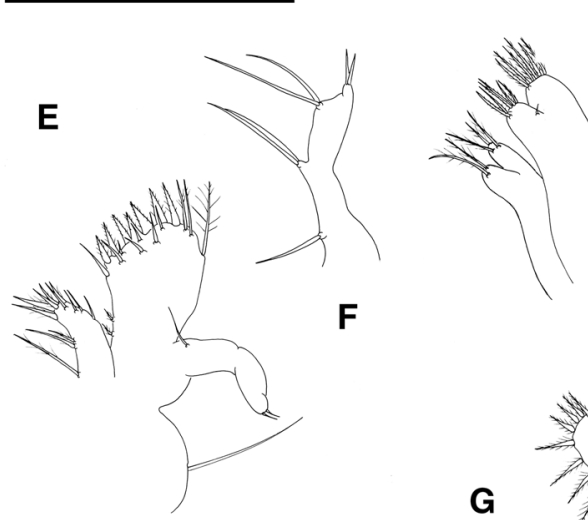

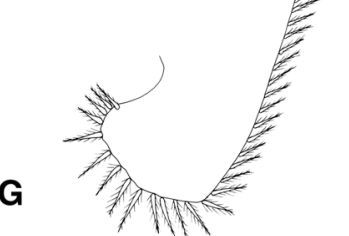

Fig. 2 Rhithropanopeus harrisii (Gould, 1841). Megalopa, a antennule; b antenna; c anomalous antenna; d mandible; e maxillule; $\mathbf{f}$ endopod of maxillule of the anomalous specimen; $\mathbf{g}$ maxilla; $\mathbf{h}$ endopod of maxilla of the anomalous specimen 


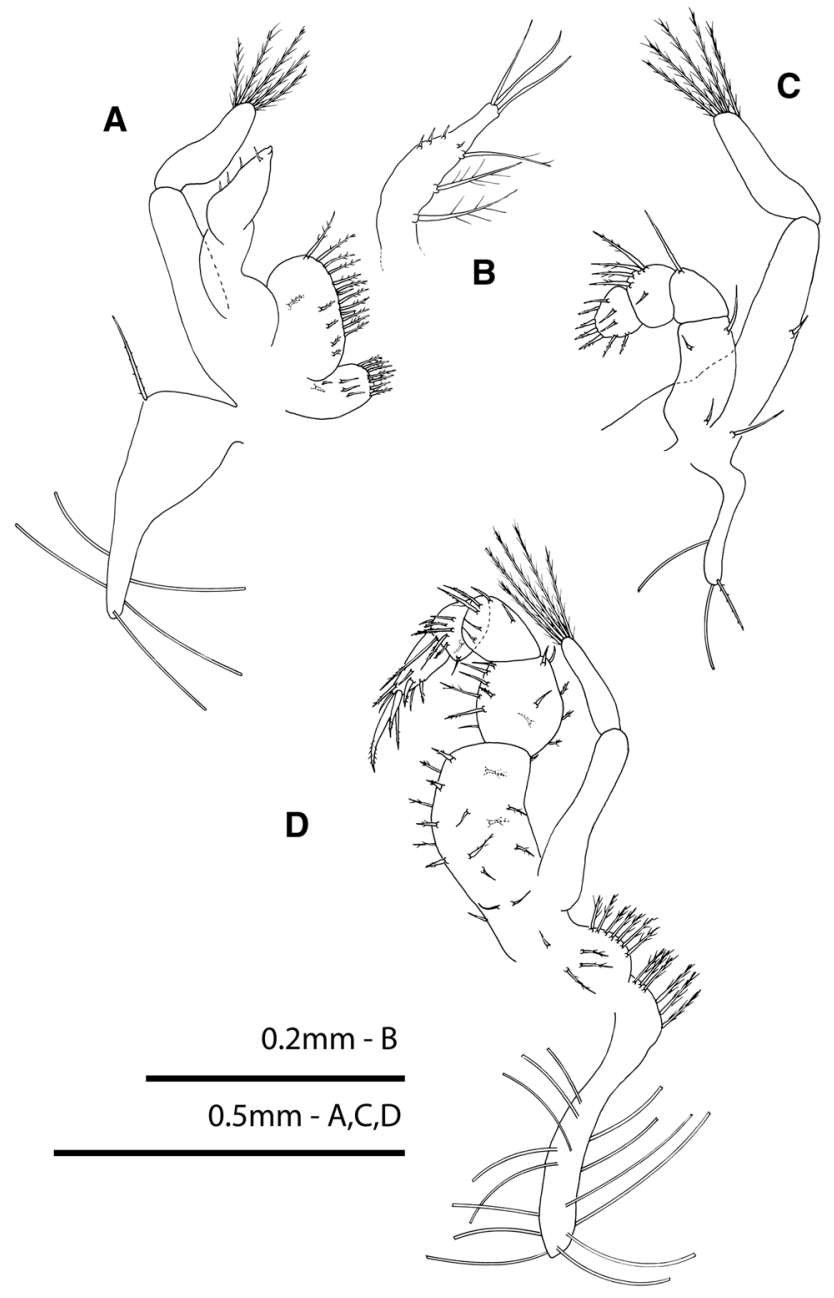

Fig. 3 Rhithropanopeus harrisii (Gould, 1841). Megalopa, a first maxilliped; $\mathbf{b}$ endopod of first maxilliped of the anomalous specimen; c second maxilliped; $\mathbf{d}$ third maxilliped

Antennule (Fig. 2a) Peduncle three-segmented, with 3 short simple setae on first segment, 2 short simple setae on median segment and 2 short simple setae plus 2 pairs of long plumodenticulate setae on distal segment; endopod unsegmented with 1 basal simple seta, 1 subterminal simple seta and 3 terminal simple setae; exopod three-segmented, with 10 aesthetascs (arranged 0, 4, 6) and 4 setae (arranged 0, 2, 2 setae).

Antenna (Fig. 2b) Peduncle three-segmented with 6 setae (arranged 4, 1, 1); flagellum six-segmented with 10 simple setae (arranged 0, 0, 1, 4, 3, 2).

Mandible (Fig. 2d) Palp two-segmented, with 5 terminal short plumodenticulate setae on distal segment.

Maxillule (Fig. 2e) Coxal endite with 12 plumose setae; basial endite with 16 setae ( 3 terminal plumodenticulate, 1 terminal sparsely plumose, 7 terminal cuspidate, 3
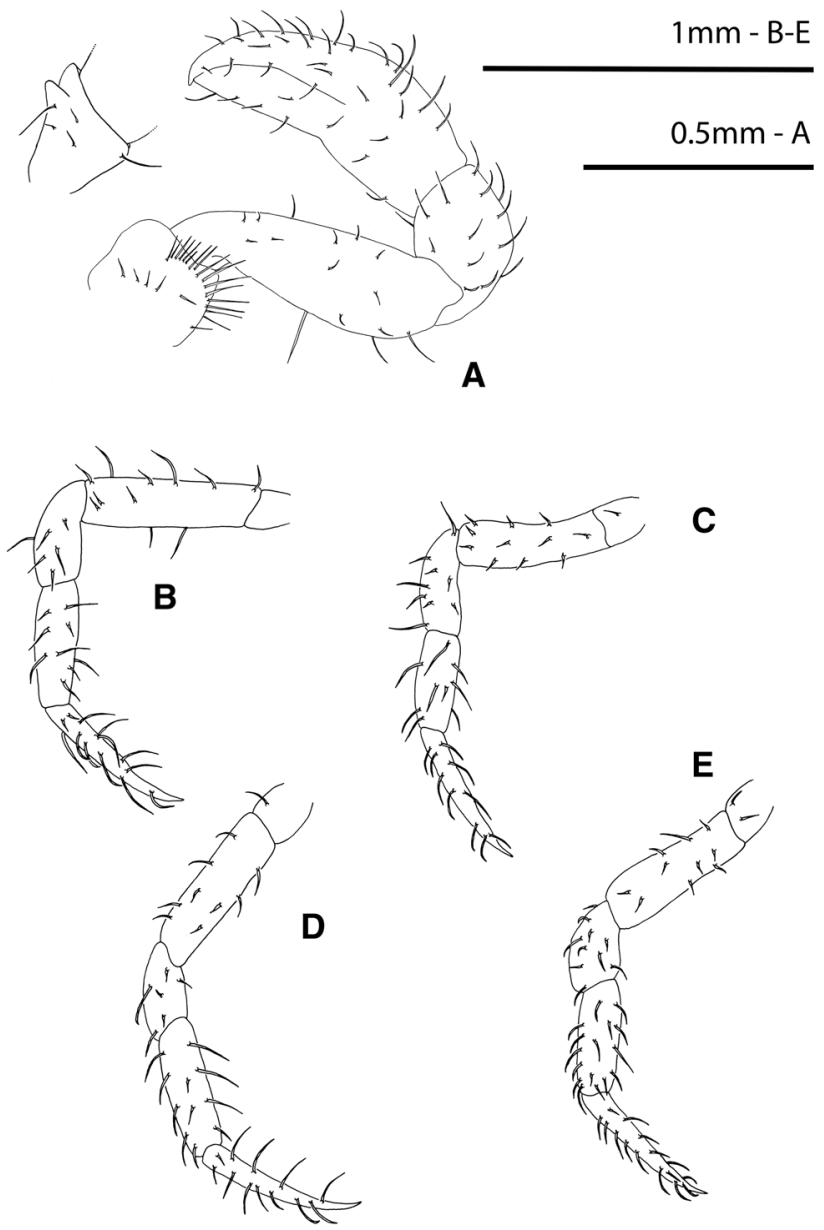

Fig. 4 Rhithropanopeus harrisii (Gould, 1841). Megalopa, a cheliped, with detail of the ischium spine; $\mathbf{b}$ second pereiopod; $\mathbf{c}$ third pereiopod; $\mathbf{d}$ fourth pereiopod; e fifth pereiopod

subterminal plumodenticulate, and 2 proximal plumodenticulate); endopod unsegmented with 1 proximal and 2 terminal simple setae; and long epipodal seta present.

Maxilla (Fig. 2g) Coxal endite bilobed with $2+3$ terminal plumose setae; basial endite bilobed with $6+6$ sparsely plumodenticulate setae; endopod unsegmented and without setae; scaphognathite with 45-47 marginal plumose setae plus 2 small simple setae on each lateral surface.

First maxilliped (Fig. 3a) Epipod well developed, triangular shaped, with 5 long simple setae and 1 proximal plumodenticulate seta; coxal endite with 5 inner simple setae and 7 terminal plumose setae; basial endite with 1 inner +4 subterminal +11 terminal sparsely plumodenticulate setae plus 2 terminal short simple setae; endopod unsegmented with 4 short terminal simple setae; exopod two-segmented, with 5 long terminal plumose setae on distal segment. 


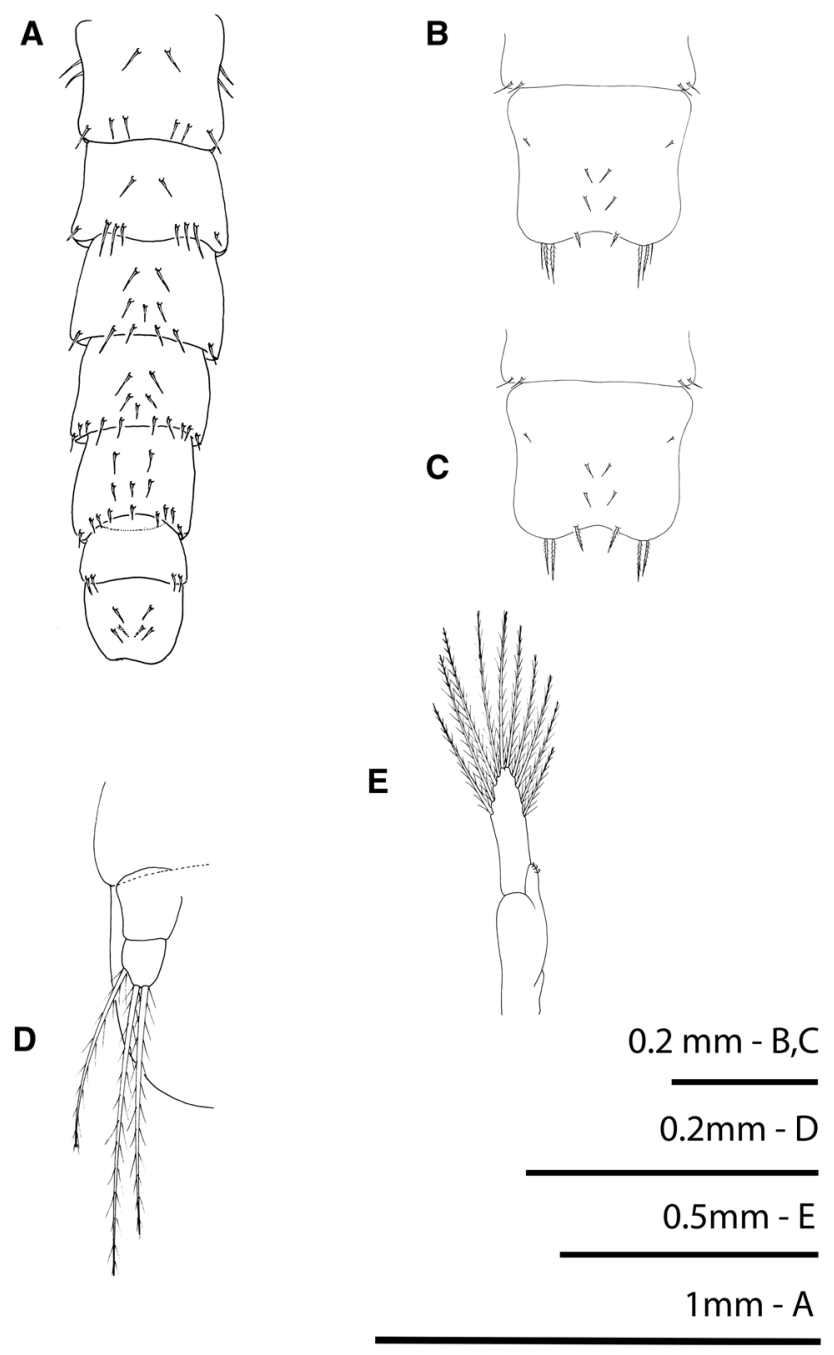

Fig. 5 Rhithropanopeus harrisii (Gould, 1841). Megalopa, a: pleon, dorsal view; (b-c) telson of an anomalous megalopa; d uropod; e third pleopod

Second maxilliped (Fig. 3c) Reduced epipod with 2 simple setae and 1 plumodenticulate seta; endopod fivesegmented, with 1 simple, 2 simple, 1 simple, 4 plumodenticulate +1 short simple, and 3 proximal simple +6 terminal plumodenticulate setae, respectively; exopod twosegmented, with 2 simple setae on proximal segment and 5 long terminal plumose setae on distal one.

Third maxilliped (Fig. 3d) Epipod well developed with a proximal marginal row of 6 plumose setae and 14 long simple setae; protopod with a marginal row of 7 plumose setae and 1 simple +3 plumose inner setae; endopod fivesegmented, with 19, 14, 6, 9 and 9 setae, respectively; exopod two-segmented with 5 long plumose setae on distal segment.

Pereiopods (Fig. 4a-e) Pereiopods 2-5 thin and setose, with long subterminal setae on dactyli. Cheliped robust and setose without remarkable recurved spines, only sometimes a small spine, never recurved.

Sternum (Fig. 1d, e) Maxilliped sternites completely fused with 6 simple setae, cheliped sternites with 4 or 6 simple setae each, pereiopod sternites $2-5$ with 3 or 4,2 or 3,1 or 2 , and 0 simple setae, respectively; sternal sutures are interrupted medially. There are two forms according to setation; the most common is illustrated in Fig. 1.

Pleon (Fig. 5a) Six somites plus telson; setation as shown.

Pleopods (Figs 5d, e) Biramous except uropods present on somites 2-5; endopod with 3 cincinuli; exopod with 10 long plumose natatory setae; uropod with 3 or 4 natatory setae on distal segment.

Description of anomalous megalopae

(Figs. 1f, 2c, f, h, 3b, 5b, c)

Size: $\quad \mathrm{CL}=1.12-1.14 \mathrm{~mm} ; \quad \mathrm{CW}=0.92-0.98 \mathrm{~mm}$;

$N=2$

All three specimens exhibited the following deviations from the typical form: cephalothorax with different shape, bearing vestiges of zoeal lateral spines, and a reduced number of setae (Fig. 1f); antennular peduncle with remains of exopodal and protopodal processes as spines (Fig. 2c); endopod of maxillule with a setation pattern of 1, 2, 2, 2 as in the zoeal endopod of the maxillule (Fig. 2f); endopod of maxilla with setation 3,2, 2 as in the zoeal maxillar endopod (Fig. 2h); endopod of first maxilliped with 3 terminal long setae plus $1+1+1$ long inner plumose setae (Fig. 3b); telson with 2-3 terminal setae in the place of furcal arms and 1 pair of marginal setae as zoeal stage (Figs 5b, c).

\section{Discussion}

Redescriptions of brachyuran larval stages are unusual, although they are necessary when previous descriptions are brief, incomplete, inaccurate or deficient, making them useless for reliable identifications. There are some cases of redescriptions in the recent literature. For instance, Aratus pisonii (H. Milne Edwards, 1837) was redescribed by Cuesta et al. (2006) considering that the previous description by Warner (1968) referred to a clearly anomalous megalopa. The most recent redescription of $D$. sayi by Marco-Herrero et al. (2013b) was necessary because the several previous descriptions were brief and inaccurate and thus inappropriate for comparative taxonomic studies. Correct descriptions of larval stages are needed for phylogenetic studies and accurate identifications of plankton- 
collected specimens. In the case of $R$. harrisii, the several previous descriptions of the megalopa from both laboratory-reared larval stages and from plankton-collected specimens are all incomplete and inaccurate and do not meet the standard proposed by Clark et al. (1998), currently followed by the majority of decapod larval morphologists.

Since the previous descriptions do not allow for an accurate identification of plankton-collected specimens, the DNA barcode was used instead. Current molecular tools ensure a correct identification of specimens collected in the field, which present clear advantages over specimens which have been reared in the laboratory. In particular, fieldcollected larvae allow for obtaining a better representation of natural morphological variability compared with larvae originated from only one or two ovigerous females cultured in the laboratory. In the present study, the $16 \mathrm{~S}$ sequences of the 10 studied megalopae, collected in the Guadalete estuary for morphological description, fit at $100 \%$ the $16 \mathrm{~S}$ sequence of $R$. harrisii from Delawere (USA) deposited in GenBank.

The morphology of the megalopae of $R$. harrisii described in the present work do not completely match the typical characters of the megalopa stages of panopeids, although Martin et al. (1984), based on zoeal morphology, included $R$. harrisii in the Group I together with the majority of panopeids. Even when the classification was based on megalopal features, the species was attributed to Group I (Martin 1988). The main differences relate to rostrum morphology, the number of segments of the antennular flagellum and the spinulation of the ischium of the cheliped.

The typical panopeid megalopa rostrum presents a remarkable spine at each basal angle, called "horns" in some papers, but these are missing in $R$. harrisii. The antennular flagellum of $R$. harrisii shows six segments while eight segments are present in other panopeids such as D. sayi (see Marco-Herrero et al. 2013b) and P. africanus (see Rodríguez and Paula 1993). The number of segments of the antennular flagellum is considered to be a conservative character at family level in other taxa (Cuesta 1999). Finally, the absence of a remarkable recurved spine on the cheliped ischium is another marked contrast to the majority of panopeids. Together with the above-mentioned differences, this feature could challenge the phylogenetic position of this species. Future molecular phylogenetic studies will help to resolve this question raised by the larval morphology.

The setation patterns of maxillule, maxilla, first, second and third maxillipeds, and sternum are described in the present work for the first time. As to the setation pattern of the sternal plates, some variability was observed, although the proportions between sternites were always similar.

In the identification key to the megalopa stages of the Mediterranean Brachyura by Pessani et al. (2004),
$R$. harrisii is differentiated by bearing three long plumose terminal setae on the distal segment of the uropod in contrast to "uropod exopod with more than 3 setae." Megalopae in the present study showed either three or four setae, and in one case, this variability occurred in the same specimen. The same variability in the setation on the exopods of the uropods has already been described by Kurata (1970).

In the present work, we also studied megalopae grown from zoeae, which I had been collected in the plankton and raised in the laboratory. There is some evidence that the culture conditions (temperature and/or feeding) were suboptimal. The megalopae which developed under these conditions showed an anomalous morphology. This kind of anomalies has already been reported in other species and not only for larvae raised in the laboratory (Willems 1982; Cuesta and Anger 2001), but also for larvae collected in the field (Cuesta et al. 2002). In all these cases, the anomalies referred to morphological character of the zoeal phase, such as the presence of short lateral spines in the cephalothorax and the setation patterns of maxillule and maxilla endopods. The available data suggest that morphological anomalies in the megalopa stage are the result of suboptimal environmental conditions (temperature, salinity, food), and that such deficiencies can occur not only during laboratory rearing but also in the natural environment.

Acknowledgments We want to thank the "Real Club Náutico" of the Puerto Santa María (Cádiz, Spain) for kindly allowing us to use their facilities. We are especially grateful to Reyes Sánchez García and Ainhoa Olaguer-Feliú who helped in collecting the larvae, Carlos Sánchez Nieto for his assistance in the laboratory work, and Dulce Subida for her careful language corrections. Thanks are also due to anonymous referees and Prof. Heinz-Dieter Franke for his editorial work. The research was carried out within the framework of the projects MEGALOPADN (CGL2009-11225) and "Transporte y reclutamiento larvario de crustáceos bentónicos litorales: importancia de los agentes forzadores costeros y regimen mareal" (CTM200500024/MAR), both co-financed by the "Ministerio de Economía y Competividad (MINECO)" Spanish Plan R + D + I and European Union FEDER funds. Elena Marco-Herrero acknowledges the predoctoral FPI Fellowship supported by MINECO (BES-2010-033297).

\section{References}

Ahyong ST, Lai JCY, Sharkey D, Colgan DJ, Ng PKL (2007) Phylogenetics of the brachyuran crabs (Crustacea: Decapoda): The status of Podotremata based on small subunit nuclear ribosomal RNA. Mol Phylogenet Evol 45:576-586

Ampuero D, Palma AT, Veliz D, Pardo LM (2010) Description, seasonal morphological variation, and molecular identification of Paraxanthus barbiger megalopae obtained from the natural environment. Helgol Mar Res 64:117-123

Chamberlain NA (1962) Ecological studies on the larval development of Rhithropanopeus harrisii (Xanthidae, Brachyura), Chesapeake Bay Institute. Johns Hopkins Univ Tech Rep 28:1-47

Clark PF (1986) North-east Atlantic crabs: an atlas of distribution. Marine Conservation Society, England 
Clark PF, Calazans DK, Pohle GW (1998) Accuracy and standardization of brachyuran larval descriptions. Invert Reprod Dev 33:127-144

Connolly CJ (1925) The larval stages and megalops of Rhithropanopeus harrisii (Gould). Contrib Can Biol Stud Biol Stn Can 2:329-334

Costlow JD, Bookhout CG (1971) The effect of cyclic temperatures on larval development in the mud-crab Rhithropanopeus harrisii. In: Crisp DJ (ed) Fourth European Marine Biology Symposium. Cambridge University Press, Cambridge, pp 211-220

Crandall KA, Fitzpatrick JFJ (1996) Crayfish molecular systematics: using a combination of procedures to estimate phylogeny. Syst Biol 45:1-26

Cuesta JA (1999) Morfología larval de la familia Grapsidae (Crustacea, Decapoda, Brachyura). Dissertation, University of Seville, Spain

Cuesta JA, Anger K (2001) Larval morphology of the sesarmid crab Armases angustipes (Dana, 1852) (Crustacea, Decapoda, Grapsoidea) reared under laboratory conditions. J Crust Biol 21:821-838

Cuesta JA, García-Raso JE, González-Gordillo JI (1991) Prim-era cita de Rhithropanopeus harrisii (Gould, 1814) (Crustacea, Decapoda, Brachyura, Xanthidae) en la Península Ibérica. Bol Inst Esp Oceanogr 7:149-153

Cuesta JA, Luppi TA, Rodríguez A, Spivak ED (2002) Morphology of the megalopal stage of Chasmagnathus granulatus Dana, 1851 (Crustacea: Decapoda: Brachyura: Varunidae), with comments on morphological anomalies. Proc Biol Soc Wash 115:391-402

Cuesta JA, García-Guerrero MU, Rodríguez A, Hendrickx ME (2006) Larval morphology of the sesarmid crab Aratus pisonii (H. Milne Edwards, 1837) (Decapoda, Brachyura, Grapsoidea) from laboratory reared material. Crustaceana 79:175-196

Florio M, Breber P, Scirocco T, Specchiulli A, Cilenti L, Lumare L (2008) Exotic species in Lesina and Varano lakes, Gargano National Park (Italy). Transit Waters Bull 2:69-79

Forward RB Jr (2009) Larval biology of the crab Rhithropanopeus harrisii (Gould): a synthesis. Biol Bull 216:243-256

Froglia C, Speranza S (1993) First record of Dyspanopeus sayi (Smith, 1869) in the Mediterranean Sea (Crustacea: Decapoda: Xanthidae). Quad Ist Ricerca Pesca Maritt 5:163-166

Gonçalves F, Ribeiro R, Soares AM (1995) Rhithropanopeus harrisii (Gould), an American crab in the estuary of the Mondego River, Portugal. J Crust Biol 15:756-762

Hood RM (1962) Studies on the larval development of Rhithropanopeus harrisii (Gould) of the family Xanthidae (Brachyura). Gulf Res Rep 1:122-130

Ingle RW (1980) British crabs. Oxford University Press, London

Kurata H (1970) Studies on the life histories of decapod Crustacea of Georgia; Part III. Larvae of decapod Crustacea of Georgia. Dissertation, University of Georgia

Landeira JM, Lozano-Soldevilla F, González-Gordillo JI (2009) Morphology of first seven larval stages of the striped soldier shrimp, Plesionika edwardsii (Brandt, 1851) (Crustacea: Decapoda: Pandalidae) from laboratory reared material. Zootaxa 1986:51-66

Marco-Herrero E, Torres AP, Cuesta JA, Guerao G, Palero F, Abelló P (2013a) The systematic position of Ergasticus (Decapoda, Brachyura) and allied genera, a molecular and morphological approach. Zool Scripta 42:427-439

Marco-Herrero E, Guerao G, Cuesta JA (2013b) Morphology of the larval stages of a Mediterranean population of the allochthonous Say's mud crab, Dyspanopeus sayi (Decapoda: Brachyura: Panopeidae). Sci Mar 77:341-352
Martin JW (1988) Phylogenetic significance of the brachyuran megalopa: evidence from the xanthidae. Symp Zool Soc Lond 59:69-102

Martin JW, Felder DL, Truesdale FM (1984) A comparative study of morphology and ontogeny in juvenile stages of four western Atlantic xanthoid crabs (Crustacea: Decapoda: Brachyura). Philos Trans R Soc Lond B 303:537-604

Micu D, Nita V, Todorova V (2010) First record of Say's mud crab Dyspanopeus sayi (Brachyura: Xanthoidea: Panopeidae) from the Black Sea. Mar Biodiver Rec 3:1-6

Mizzan L (1995) Notes on the presence and diffusion of Dyspanopeus sayi (Smith, 1869) (Crustacea, Decapoda, Xanthidae) in the Venetian Lagoon. Boll Mus Civ Stor NatVenezia 44:121-130

Nizinski MS (2003) Annotated checklist of decapod crustaceans of Atlantic coastal and continental shelf waters of the United States. Proc Biol Soc Wash 116:96-157

Pan M, Mc Beath A, Hay S, Pierce G, Cunningham C (2008) Realtime PCR assay for detection and relative quantification of Liocarcinus depurator larvae from plankton samples. Mar Biol 153:859-870

Pardo LM, Ampuero D, Veliz D (2009) Using morphological and molecular tools to identify megalopae larvae collected in the field: the case of sympatric Cancer crabs. J Mar Biol Ass UK 89:481-490

Pessani D, Tirelli T, Flagellal S (2004) Key for the identification of Mediterranean brachyuran megalopae. Mediterranean Mar Sci 5:53-64

Porter ML, Pérez-Losada M, Crandall KA (2005) Model-based multilocus estimation of decapod phylogeny and divergence times. Mol Phylogenet Evol 37:355-369

Projecto-Garcia J, Cabral H, Schubart CD (2010) High regional differentiation in a North American crab species throughout its native range and invaded European waters: a phylogeographic analysis. Biol Invasions 12:253-263

Rodríguez A, Paula J (1993) The larval and postlarval development of the mud crab Panopeus africanus A. Milne Edwards (Crustacea: Decapoda: Xanthidae), reared in the laboratory. J Crust Biol 13:296-308

Schubart CD, Diesel R, Hedges SB (1998) Rapid evolution to terrestrial life in Jamaican crabs. Nature 393:363-365

Schubart CD, Cuesta JA, Diesel R, Felder DL (2000) Molecular phylogeny, taxonomy, and evolution of non marine lineages within the American grapsoid crabs (Crustacea: Brachyura). Mol Phylogenet Evol 15:179-190

Schubart CD, Cuesta JA, Rodríguez A (2001) Molecular phylogeny of the crab genus Brachynotus (Brachyura: Varunidae) based on the 16S rRNA gene. Hydrobiology 449:41-46

Schubart CD, Cuesta JA, Felder DL (2002) Glyptograpsidae, a new brachyuran family from Central America: Larval and adult morphology, and a molecular phylogeny of the Grapsoidea. J Crust Biol 22:28-44

Schubart CD, Guerao G, Abelló P (2012) First record and evidence of an established population of the North American mud crab Dyspanopeus sayi (Brachyura: Heterotremata: Panopeidae) in the western Mediterranean. Sci Mar 76:79-85

Spivak ED, Schubart CD (2003) Species status in question: a morphometric and molecular comparison of Cyrtograpsus affinis and C. altimanus (Decapoda, Brachyura, Varunidae). J Crust Biol 23:212-222

Vaz S, ter Hofstede R, Martin J, Dewarumez JM, Verin Y, Le Roy D, Heessen H, Daan N (2007) Benthic invertebrates community structure inferred from bottom trawl hauls observations and its 
relationships to abiotic conditions in the southern North Sea. ICES Technical Report 'Structure and dynamics of the benthos in ICES waters' CM 2007/A 03, pp 1-21

Warner GF (1968) The larval development of the mangrove tree crab Aratus pisonii (H. Milne Edwards), reared in laboratory (Brachyura, Grapsidae). Crustaceana 2:249-258
Willems KA (1982) Larval development of the land crab Gecarcinus lateralis lateralis (Fréminville, 1835) (Brachyura: Gecarcinidae) reared in the laboratory. J Crust Biol 2:180-201 